\title{
MRC rejects call for radiation tests inquiry
}

London. Britain's Medical Research Council (MRC) is resisting calls for an inquiry into revelations last week by a television documentary that pregnant women and dead children were used during the $1950 \mathrm{~s}$ and $60 \mathrm{~s}$, often without consent, in experiments funded by the council to test the effects of nuclear fallout.

The documentary included interviews with patients - some of whom were never informed of the nature of the tests or, indeed, that they were part of an experiment - who believe that their exposure to radiation may have triggered late onset of cancer.

But the research council has rejected the need for a follow-up inquiry along the lines of one in the United States, where President Clinton has ordered an investigation into military-backed radiation tests on cancer patients between 1940 and 1974 (see Nature 367, 303; 1994).

"The MRC will take no action," says David Evered, deputy chief executive of the MRC. He explains that an inquiry would be costly, and that there would be problems in identifying the people involved. "I know this is an important question, but I suggest we have better and more important things to spend MRC money on."

Evered points out that it was "not standard practice to ask permission [for tests on the deceased] in those days", as there was no requirement to seek permission for a postmortem examination before the 1961 Tissue Act. After the programme was transmitted, the MRC set up a telephone helpline for concerned patients and relatives, telling them that there was nothing to fear.

"These were not radiation experiments as

non-weapons laboratories. The relevant House committees have reduced these allocations to $\$ 25$ million for the weapons laboratories, and zero for the rest.

At Sandia, technology transfer manager Warren Siemens hopes that most of the laboratory's CRADAs - which generally last for three years - will be maintained with money from the weapons stewardship programme.

If there is no extra money for the weapons programme - and the latest House proposal allows none - or if the language says that the CRADAs cannot be rolled over into the main programme, then "we'd have to terminate all the CRADAs and seek to renegotiate them". At that point, he predicts, industry would pack up its bags and go home.

Neither Congressional staff, the DOE or the laboratories themselves are ready to predict exactly what impact the House budget proposal would have on CRADAs. Republicans say they support CRADAs; even as the money for them is being decimated, House subcommittees held such," says Evered in a statement released after the programme. "Although very small doses of radioactive materials were used in tests in order to help solve important health problems, established techniques were used and considerable research over many years has not shown any adverse health effects from any such tests."

Evered's confidence in the lack of hazards in the experiments however, is not universally shared. Some radiologists contin-

\section{IMAGE UNAVAILABLE FOR COPYRIGHT REASONS}

\section{Were patients in radioactivity experiments} as carefully protected as workers (above)?

ue to claim that the risk of contracting cancers from exposure to low radiation, though small, should not be ignored.

Others insist the risk needs to be placed in context. "Any radiation dose carries the risk of a later onset of cancer," says one. "But this risk has to be compared with the ordinary risk of contracting cancer, which is

supportive hearings last week, with a view to bipartisan legislation to improve their efficacy. But the Republicans say that CRADAs should compete on equal terms for programme funds.

Officials familiar with the history of the CRADAs, however, doubt that they will be able to do that. The money was set aside after 1989, they say, precisely because the laboratories were failing to establish collaboration with industry using existing programme funds. Industry was interested in such deals, officials say, but given the choice, laboratory scientists preferred to spend their own money on their own projects.

Even 20 years ago it was clear that Sandia and Los Alamos could not survive on nuclear weapons work alone, and since then they have turned for support to the energy programmes launched by President Jimmy Carter, to President Ronald Reagan's Strategic Defence Initiative and, most recently, to technology transfer. The concern of the 16,000 staff at the two laboratories is where can they turn next?

Colin Macilwain quite high in populations such as ours."

The MRC's decision not to hold an inquiry is likely to remain controversial. Richard Guthrie, a spokesman for the Verification Technology Information Centre (VERTIC) in London, says a thorough investigation would be the best way to assess the extent of radiation damage on those involved in the experiments. "Even if below background level, the radiation dose must have been sufficient to interfere with the body in some way, otherwise there was no point in the experiments," says Guthrie.

The hour-long television documentary, Deadly Experiments, based its report on hospital records and research results published in scientific and medical journals. According to the programme's producers John Brownlow and Joe Bullman, both of the London-based production company Twenty-Twenty Television, the experiments had two broad aims.

One was to evaluate the risk to soldiers in the event of exposure to a nuclear explosion. One set of tests, for example, involved irradiating 6,000 bone specimens taken from dead children in north Wales between 1955 and 1970; another experiment, not linked to the MRC, involved administering total-body radiation to 17 terminally ill patients at the Churchill Hospital in Oxford.

The second aim of experiments was to monitor the effects on the human body of nuclear accidents such as the 1957 fire at the nuclear fuel reprocessing plant at Windscale, in the north of England, which led to a release of radioactive iodine into the atmosphere. The programme-makers allege that in a series of such tests carried out between 1952 and 1957, 30 pregnant mothers were administered radioactive iodine, and the effects later analyzed at the UK Atomic Energy Research Establishment at Harwell in Oxfordshire.

Another MRC experiment involved administering radioactive iron to 21 Punjabi women living in Coventry in the West Midlands. The women were fed chapatis unleavened bread - laced with radioactive iron, delivered on alternate days.

The women claim they were never informed of the bread's ingredients, or why they were taken to Harwell, where the results were analysed. But the MRC insists that there was nothing secretive about their experiments which, they say, have always been in the public domain and were performed after concern from the department of health of iron-deficiency among Asian women.

The use of radioactive iodine in pregnant women also had a medical purpose, a spokesman says, namely to trace the changing function of the thyroid gland during pregnancy, which often leads to an increase in thyroid diseases.

Ehsan Masood 